\title{
The Barriers to Implementing Multiple Teaching Techniques in Tourism and Hotels Higher Education: The Case of Helwan University
}

\author{
Mai Baher Omar Mohamed Tawfik Essawy \\ Faculty of Tourism and Hotels, Helwan University
}

\begin{abstract}
This research focuses on determining twenty three potential barriers pertaining to four main constructs of barriers (classroom environment, students, resources and lecturers' competence) affecting the implementation of multiple teaching techniques. Via a self-administered questionnaire with the staff members of the Faculty of Tourism and Hotels of Helwan University, nine barriers were identified. The most prominent barrier was the lack of up-to-date classroom equipment. Other identified barriers through this investigation include: the large number of students enrolled, the poor design of classrooms, the lack of air conditions in classrooms, the short time of lectures, the poor communication skills of students, the economic background of students, the budgetary constraints of the faculty and the lack of relevant courses offered to faculty members. The results also revealed significant differences among respondents based on their years of teaching experience and their perceptions towards each barrier. Implications and recommendations for further research are also offered.
\end{abstract}

Keywords: Multiple teaching techniques, barriers of learning, active learning, higher education, tourism and hotels.

\section{Introduction}

The tourism industry is a labor-intensive service industry. Its success is dependent on the availability of qualified personnel to deliver, operate and manage the touristic product. There is a vital need to implement various teaching methods and techniques to guarantee that students and faculties can contribute to the tourism community and be active in forming the future (Liburd et al., 2011). Enhancing the learning process of students to acquire the needed talents of the tourism and hospitality industry is a key issue (Elsayed et al., 2011). The learning process is more than just passively absorbing information where learners are passive receivers (Chou, 2006; De Rose et al., 2014). This process must become an active learning experience full of innovative concepts and bright ideas. It is based on a belief that the more students share, discuss and collaboratively revise and draw conclusions the more they learn. Active participations and discussions are, therefore, key factors in the learning process (Lin and Hsieh, 2001). Through constant discussions and interactions students gain insights that would be difficult for them to achieve on their own (Stahl, 2006). The idea is to make concrete and abstract connections with other participants in the learning process.

Education, like almost every other area of our society, has evolved in leaps and bounds in recent years. Traditional teaching techniques, based mainly on a teacher explaining a topic and students taking notes, may still be useful in some occasions, but education today revolves more around encouraging the student to awaken their curiosity and desire to learn (Prince, 2004). A number of different teaching techniques emerged due to this change in education. Many of these teaching techniques are not actually new; however, the use of technology in the classroom has simply given education a new lease of life allowing us to approach old ideas in new ways. Today's faculty members need to have a large outlook on teaching techniques with emphasis on encouraging interactions and coproduction of text and communication (Minocha and Thomas, 2007; Sigala, 2007).They must realize that newer, more tactful instructional approaches are critically important to improving any student's educational career. Educators can generate much of the excitement and energy they desire by introducing creativity into the lives of their students and by supporting their desire to know. The practical consequence is that a student's desire to know more about a subject is more important than a measure of performance at any point in time (Ruth and Houghton, 2009).

Higher education has been challenged to improve students' learning experiences. There are likely to be perceived barriers to implementing multiple teaching techniques. Some of these obstacles are to be with the educators themselves through traditional and outdated beliefs with the risks associated with using active learning 
techniques (Adams, 2010). Other types of difficulties include outdated administrative policies and procedures, poor student preparation for multiple teaching methods and inappropriate budgets for instructional improvements (Hutyra, 2004). This study focused on four perceived barriers. These barriers are: the student, the resources, the classroom environmental barrier and the lecturers' competence barrier. These barriers can be real and their impact upon higher education could be enormous. Determining and eliminating these barriers will make the teaching and learning process more meaningful and rewarding. The aim of the present study is to measure the academic staff members' perceptions towards the barriers affecting the implementation of multiple teaching techniques. This aim was achieved in the context of the Faculty of Tourism and Hotels of Helwan University.

\section{Literature Review \\ Multiple teaching techniques}

Multiple teaching techniques are defined as instructional tactics and activities used by lecturers and professors for helping students progress from where they are to where they must be (Cakula, 2006). Higher tourism and hospitality education requires using a variety of multiple teaching techniques including, but not limited to, lectures and discussions, collaborative learning, computer-assisted instruction, distance learning, learning by teaching, simulation and on-the-job internships (Elsayed et al., 2011). These multiple teaching techniques are developed to ensure that students develop the knowledge, attitudes and the necessary skills for success in their career fields (Wolfe, 2006). These teaching techniques involve cognitive, affective and psychomotor learning outcomes using the latest and most advanced technologies needed in the classroom. Thus, the use of multiple teaching techniques tends to promote enhanced learning opportunities (Junco and Mastrodicasa, 2007).

According to Hundley (2007), multiple teaching techniques gave educators three major advantages in the classroom. These include: (1) mind-to-mind interaction between lecturers and students that is refined and supported; (2) multiple teaching techniques reflect effective teaching practices and have the potential for achieving learning goals with all students; and (3) learning goals are more demanding and, therefore, students are forced to greater achievements. Furthermore, the use of these techniques in the classroom is vital because of their powerful impact on student learning. Littlejohn and Watson (2004) stated that professors must engage their students in active learning techniques in order to promote cognitive thinking using analysis, synthesis and evaluation that help students develop skills rather than simply transmitting information to them. Hence, applying multiple teaching techniques in a classroom promote active learning, allow students to actively participate in the learning process by talking to each other and listening to other points of view, gain self-confidence and strengthen their speaking and communication skills.

\section{Barriers to implementing multiple teaching techniques The classroom environmental barrier}

Although there are numerous perceived environmental barriers to using multiple teaching techniques, design elements of the classroom, class size and time allotted for the instruction appear to have the most profound influence upon the educational process (American Society for Training and Development, 1989).The climate of a learning classroom is a direct result of the actions and activities of its participants. If students are not learning, the lecturer needs to change his or her approach to teaching them.

On many occasions, faculty staff members have very little input into the environmental conditions, i.e., heat, noise and light of a classroom. However, seating arrangements may be altered enough to accommodate and encourage better student involvement and discussions despite the environmental conditions. Redesigning seating arrangements may promote an active learning environment. Class size is a major perceived barrier when using multiple teaching techniques (Chopoorian et al., 2001). The importance of size (number of students) depends upon educational goals and that large classes are simply not as effective as small classes for retention of knowledge, critical thinking and attitude change. Furthermore, educators need to realize the importance of time in the classroom. Therefore, educators need to give students opportunities to talk, write, do classroom or field projects or carry out other activities that stimulate or reveal their knowledge and thinking. A favorable learning environment requires necessary monitoring; active guidance of educators and effective channels for students to 
learn through networks that enhance the learning performance via collaboration. This, indeed, is not offered neither in a large classroom nor in a short lecture (Scott, 2007).

\section{The Students barrier}

The socioeconomic and cultural pattern of students has changed (Trahan, 2009). Personal awareness, technological creativity and a willingness to be more open-minded, increased with the trend of multiculturalism. Teaching requires sensitivity to different communication styles especially when students have varied cultural backgrounds (Wyckoff, 2001). Besides cultural changes, the modern day classroom atmosphere shows age differences, changing life styles and interpersonal dealings of students and professors - many of them emotional, subtle, and symbolic - which strongly affect student morale, motivation, and learning. For educators, the question is not simply one of trainable skills or attitudes but recognizing that students who have essentially different instincts are in the same classroom (De Lorenzo and Abbott, 2004). Additionally, students are unlikely or unable to be successful when limited to activities not compatible with the attitudes brought into the learning situation. Also, Students value the exchange of ideas and the opportunity to increase their understanding of course materials through working in groups (Hanson and Moser, 2003). As students become more and more diverse, the ways of teaching them must be dynamic and innovative (Eraqi et al., 2011).

\section{The resources barrier}

For many faculties, the costs of providing educational opportunities have increased over the years. Most of them are struggling to operate within an established paradigm that is failing due to inadequate resources (Adams, 2010). Resources would include finance, physical and technological infrastructure, materials and academic support services. With the costs of education continuing to soar, faculties are seeking financial resources from tourism corporations and the tourism industry. Chang and Chang (2012) established that local tourism industries are keen to offer funds to faculties of tourism and hotel management that have training programs and courses tailored to the needs of the industry. With adequate financial assistance and the technical guidance of the industry, more advanced teaching techniques could be implemented.

\section{The lecturers' abilities and competence barrier:}

The quality and quantity of trained teaching personnel is a major component of concern for every institution of higher education. Trained and professional lecturers should be actively promoting students to use effective learning techniques (Sigala, 2007). A variety of styles and techniques can expose students to much information and, thus, knowledge is expanded. Furthermore, Elsayed et al. (2011) emphasized that it is not enough to simply use techniques in our teaching, but we must train students on how to do this on their own when studying. Faculties need to concentrate on teaching students hands-on skills and should move away from the classroom as a think tank approach. Moreover, employers want educators to give students project management experiences, opportunities to work in teams and exposure to technology used in the workplace (Ghany and Latif, 2012). If a major goal of education is to produce lifelong strategic learners, then it is the responsibility of each faculty of tourism and hotel management educator to teach students how to learn as well as what to learn (Raybould and Wilkins, 2005).

Present university educators are teaching the past pupils of the e-generation. The only way to shorten the gap between educators and students is that educators be familiar with the application of information technology. Afifi (2011) stated a lack of commitment to technology at the highest echelons of administration can be disastrous. Modern technology provides the extra benefits of creativity and better problem solving techniques, enriching the human mind with knowledge (Eraqi et al., 2011). However, the use of technology has some costs. Equipment costs if you do it well; costs more if you do it poorly; and it costs even more if you do not do it at all (Scornavacca and Marshall, 2007). The costs of utilizing modern classroom teaching equipment are tremendous but the rewards are spectacular and powerful. Faculties of tourism and hospitality have to utilize the resources of information technology, be open to students during classes, arrange different learning periods according to the interests of students and arrange professional lecturers for instructions so as to enhance the learning performance of students (Chang and Chang, 2012; Zwyno and Waalen, 2001). 


\section{Research Design and Methodology Population of the Study}

This research is based on responses from the staff members of the Faculty of Tourism and Hotels of Helwan University. There are approximately more than 70 staff members at the investigated faculty. This represents a substantial share from the staff members of all state-wide faculties of tourism and hotels in Egypt. This is largely due to the fact that the chosen faculty is the oldest faculty of tourism and hotels in Egypt. The staff members of the chosen faculty also comprise a wide assortment of tourism and hotels related occupations and teaching experience. Beside the traditional undergraduate and postgraduate programs, the selected faculty is engaged in various teaching and training projects (edu-training with Americana and McDonalds, Masr El-Kheir training programs, Master of Aviation Management, etc) that may urge the staff members to use various teaching strategies and techniques. All these issues render the staff members of the selected faculty an appropriate population for this study.

\section{The research method}

After analyzing the prominent methods with regard to their applicability as instruments for identifying the educational barriers in research studies, two methods were identified: the observation and the interview. It is impossible solely to 'observe' the indicators of the current research variables. These data needed to be gathered can only be found in the expert knowledge of lecturers and professors. This means bilateral communication between the researchers and lectures and professors was necessary. Observation refers only to the collection of experience within a non-communicative process (De Vaus, 2002). For this reason, observation was not considered as a suitable instrument. So, the interview remained a communicative instrument that is able to investigate the relationship between variables consisting of complex indicators. It then had to be made clear whether the interview was supposed to be done orally or with questionnaire. Because the variables were known (different types of barriers) and can be transferred into standardized questions which can be listed in a determined sequence, the issue was decided for the interview with questionnaire. Further arguments supporting this decision included the much easier and cheaper access to potential respondents. Additionally, the use of questionnaires implied the generation of deductive results.

\section{Procedures and measurements}

The research instrument (a survey) used in this study was adapted from the work of Hutyra (2004). This is because Hutyra followed a rigorous methodology for developing and validating the original research instrument. Additionally, it is the most comprehensive research instrument available in the literature that focuses on the four barriers (students, resources, classroom environment and lecturers' competence) impeding the implementation of multiple teaching techniques.

Several question formats were presented on the survey. Many of the questions were presented so that the participants could respond on a 5-point Likert-type scale $(1=$ strongly disagree to $5=$ strongly agree $)$. The survey instrument was designed to measure perceptions towards the barriers of using multiple teaching techniques in the tourism and hotels context. Perceptions about these barriers were measured by 23 questions recorded on five-point scales. The demographic characteristics of respondents were assessed in terms of working department, years of teaching experience, job title and attendance of relevant training courses. The instrument is presented in the appendix.

Each staff member at the Faculty of Tourism and Hotels of Helwan University was personally contacted to fill in the survey. A copy of the survey was left with each staff member after an explanation of the aim of the research and ethical considerations of the study. Approximately after four weeks, the researchers managed to collect 50 valid questionnaires. This represents $69.4 \%$ of the total staff members of the chosen faculty. This was considered an acceptable response rate for this study.

\section{The research hypotheses}

Based on the literature review discussed earlier the following hypotheses were proposed: 
Hypothesis 1: There are significant differences among the perceptions of faculty members based on their job titles (lectures, associate professors and professors) towards each of the four perceived barriers of implementing multiple teaching techniques.

Hypothesis 2: There are significant differences in the perceptions of faculty members categorized by years of teaching experience towards each of the four perceived barriers of implementing multiple teaching techniques.

\section{Statistical analysis}

The Statistical Package for Social Sciences (SPSS) was used to analyze the results. Firstly, the reliability of the questionnaire was conducted using Cronbach's Alpha statistical data procedures. Cronbach's alpha is a model of internal consistency reliability that is calculated using the average inter-item correlation. When a set of items may represent a one-dimensional latent construct, Cronbach's alpha is higher or equal to 0.60. On the other hand, a low Cronbach's alpha $(<0.40)$ is an indication that data may have a multidimensional structure (Malhotra and Saunders, 2010). Secondly, the median was used for indentifying the key barriers impeding the implementation of multiple teaching techniques. The median is effectively the middle value. It is the score that divides the respondents 50:50 so that half of the responses are above the median and half are below. It is used in reporting the research results because it is argued by Hourigan (2011) that it is less likely to be skewed by outliers than a mean (i.e. average). Following the methodology of Hourigan (2011) the median is used in reporting the results of this study to identify barriers that are:

- Needing critical attention (median $\geq 4.7$ ),

- Needing improvement (median 3.6-4.69),

- Meeting aspirations (median 3.01-3.59), or

- Outstanding (median $\leq 3$ ).

Finally, a series of one-way ANOVAs were performed to determine if the total number of teaching experience years and job titles affect the staff members' perceptions of multiple teaching barriers.

\section{Results}

\section{The demographics of respondents}

The demographic characteristics of respondents were assessed in terms of job title, scientific department, years of teaching experience and the attendance of training courses relevant to the use of multiple teaching techniques (Table 1). It is apparent from Table 1 that the majority of respondents (40\%) were lecturers followed by associate professors (38\%) and professors $(22 \%)$. Additionally, most respondents were from the tourism studies department (38\%) and staff members from the hotel management department had the least contribution in this study. It is also evident from the same table that the majority of respondents (54\%) had working experiences between 6 to 10 years and more than half $(52 \%)$ did not attend relevant training courses.

Table 1. The demographic characteristics of respondents

\begin{tabular}{|l|c|c|}
\hline \multicolumn{1}{|c|}{ Characteristics } & Frequency & Percentage \\
\hline Job title & 20 & 40 \\
\hline Lecturer & 19 & 38 \\
\hline Associate professor & 11 & 22 \\
\hline Professor & 19 & 38 \\
\hline Scientific department & 14 & 28 \\
\hline Tourism studies & 17 & 34 \\
\hline Hotel management & 13 & 26 \\
\hline Tourism guidance & 27 & 54 \\
\hline Years of teaching experience (years) & 6 & 12 \\
\hline $1-5$ & 4 & 8 \\
\hline $6-10$ & 24 & 48 \\
\hline $11-15$ & 26 & 52 \\
\hline $16-20$ & \multicolumn{1}{|l|}{} \\
\hline Attending training courses & \multicolumn{1}{|l|}{} \\
\hline Yes & \multicolumn{1}{|l|}{} \\
\hline No &
\end{tabular}




\section{Barriers of implementing multiple teaching techniques}

Table 2 presents the barriers to implementing multiple teaching techniques related to the classroom environment. It is evident from the table that out of the six potential barriers related to the classroom environment only four were perceived to be barriers in implementing multiple teaching techniques. The large number of students attending lectures was considered as the main barrier related to the classroom environment (median $=4.50)$. This result is in agreement with the research of Hutyra (2004). This was followed by the lack of air conditions in classrooms $($ median $=4)$, the short time of lectures $($ median $=4)$ and the poor designs of classrooms $($ median $=$ $3.50)$.

Table 2. The barrier analyses related to the classroom environment

\begin{tabular}{|l|c|c|c|}
\hline Barriers* & Median & $\begin{array}{l}\text { Barrier or } \\
\text { not }\end{array}$ & Perceptions \\
\hline $\begin{array}{l}\text { The large class size (number of students) is a } \\
\text { barrier affecting the use of multiple teaching } \\
\text { techniques. }\end{array}$ & 4.50 & Yes & Need improvement \\
\hline $\begin{array}{l}\text { The poor designs of the classrooms in my faculty } \\
\text { are barriers affecting the use of multiple teaching } \\
\text { techniques. }\end{array}$ & 3.50 & Yes & Need improvement \\
\hline $\begin{array}{l}\text { The noise and distractions in my faculty are barriers } \\
\text { affecting my utilization of multiple teaching } \\
\text { techniques. }\end{array}$ & 3.00 & No & Outstanding \\
\hline $\begin{array}{l}\text { The lack of air conditioning in my classroom is a } \\
\text { barrier affecting the use of multiple teaching } \\
\text { techniques. }\end{array}$ & 4.00 & Yes & Need improvement \\
\hline $\begin{array}{l}\text { The short time of my lectures is a barrier affecting } \\
\text { my use of multiple teaching techniques. }\end{array}$ & 4.00 & Yes & Need improvement \\
\hline $\begin{array}{l}\text { Inadequate lighting in classrooms is a barrier } \\
\text { affecting the use of multiple teaching techniques. }\end{array}$ & 2.00 & No & Outstanding \\
\hline Reliability (Cronbach's alpha) & & & $\mathbf{0 . 7 6 3}$ \\
\hline
\end{tabular}

*Five-point scale: 1 = strongly disagree to $5=$ strongly agree

Table 3 shows the barriers related to students. The analysis revealed only two barriers related to students. These are related to the poor communication skills of students and the economic backgrounds of students. The results driven from this study completely contradicts with the research of Hutyra (2004). In the context of computerrelated teaching Hutyra found that these two items did not affect the use of multiple teaching techniques. The respondents considered all the remaining items used in the student construct to be outstanding and did not affect the implementation of multiple teaching strategies.

Table 3. The barrier analyses related to students

\begin{tabular}{|l|c|c|l|}
\hline Barriers* & Median & $\begin{array}{l}\text { Barrier or } \\
\text { not }\end{array}$ & Perceptions \\
\hline $\begin{array}{l}\text { Teaching to disabled students is a barrier affecting } \\
\text { the use of multiple teaching techniques. }\end{array}$ & 2.00 & No & Outstanding \\
\hline $\begin{array}{l}\text { The age of my students is a barrier affecting my use } \\
\text { of multiple teaching techniques. }\end{array}$ & 2.00 & No & Outstanding \\
\hline $\begin{array}{l}\text { Non-traditional students (e.g. open learning) are } \\
\text { barriers affecting the use of multiple teaching } \\
\text { techniques. }\end{array}$ & 2.00 & Outstanding \\
\hline $\begin{array}{l}\text { The poor communication skills of my students are } \\
\text { barriers affecting the use of multiple teaching } \\
\text { techniques. }\end{array}$ & 4.00 & Yes & Need improvement \\
\hline $\begin{array}{l}\text { The economic backgrounds of students are barriers } \\
\text { affecting the use of multiple teaching techniques. }\end{array}$ & 4.00 & Yes & Need improvement \\
\hline
\end{tabular}




\begin{tabular}{|l|c|c|c|}
\hline $\begin{array}{l}\text { The cultural heritages of my students are barriers } \\
\text { affecting the use of multiple teaching techniques. }\end{array}$ & 2.00 & No & Outstanding \\
\hline $\begin{array}{l}\text { Bad student discipline is a barrier affecting the use } \\
\text { of multiple teaching techniques. }\end{array}$ & 2.00 & No & Outstanding \\
\hline Reliability (Cronbach's alpha) & & & $\mathbf{0 . 6 1 5}$ \\
\hline
\end{tabular}

*Five-point scale: 1 = strongly disagree to 5 = strongly agree

Table 4 presents the barriers related to the availability of the resources necessary for the implementation of multiple teaching techniques. It is clear from Table 4 that the accessibility to up-to-date classroom equipment is one of the most critical barriers affecting the use of multiple teaching techniques. This could be due to the lack of financial resources needed to equip classrooms with the necessary equipment. This reasoning is quite rationale because respondents also perceived budgetary constraints as important factors impeding the implementation of multiple teaching techniques.

Table 4. The barrier analyses related to resources availability

\begin{tabular}{|l|c|c|c|}
\hline Barriers* & Median & $\begin{array}{l}\text { Barrier or } \\
\text { not }\end{array}$ & Perceptions \\
\hline $\begin{array}{l}\text { The budgetary constraints of my faculty are barriers } \\
\text { affecting my utilization of multiple teaching } \\
\text { techniques. }\end{array}$ & 4.5 & Yes & Need improvement \\
\hline $\begin{array}{l}\text { Accessibility of state-of-the-art classroom teaching } \\
\text { equipment is a barrier affecting the use of multiple } \\
\text { teaching techniques. }\end{array}$ & 5.0 & Yes & $\begin{array}{c}\text { Need critical } \\
\text { attention }\end{array}$ \\
\hline $\begin{array}{l}\text { The administration in my faculty supports the use } \\
\text { of multiple teaching techniques**. }\end{array}$ & 1.5 & No & Outstanding \\
\hline Reliability (Cronbach's alpha) & & & $\mathbf{0 . 6 1 6}$ \\
\hline
\end{tabular}

*Five-point scale: $1=$ strongly disagree to $5=$ strongly agree

**Item was reverse coded.

Table 5 reports the barriers related to staff members' abilities and competence of using multiple teaching techniques. The table clearly identifies that there is only one barrier related to staff competence and abilities affecting the implementation of multiple teaching techniques. This is the lack of professional courses related to the professional development of university lecturers. More than half of respondents (52\%) did not attend any courses related to the use of multiple teaching techniques. This result contradicts with the work of Hutyra (2004).

Table5. The barriers analysis related to lecturers' abilities and competence.

\begin{tabular}{|l|l|l|l|}
\hline Barriers* & Median & $\begin{array}{l}\text { Barrier or } \\
\text { not }\end{array}$ & Perceptions \\
\hline $\begin{array}{l}\text { Teaching courses with other staff members of my } \\
\text { department is a barrier affecting the use of multiple } \\
\text { teaching techniques. }\end{array}$ & 2.00 & No & Outstanding \\
\hline $\begin{array}{l}\text { The lack of courses offered by my university in } \\
\text { professional lecturer development is a barrier } \\
\text { affecting the use of multiple teaching techniques. }\end{array}$ & 4.00 & Yes & Need improvement \\
\hline $\begin{array}{l}\text { My educational background is a barrier affecting } \\
\text { the use of multiple teaching techniques. }\end{array}$ & 2.00 & No & Outstanding \\
\hline $\begin{array}{l}\text { I am confident that I can effectively use all of the } \\
\text { multiple teaching techniques in my lectures**. }\end{array}$ & 2.00 & No & Outstanding \\
\hline $\begin{array}{l}\text { I understand when to use the appropriate teaching } \\
\text { technique which best achieves the desired learning } \\
\text { outcome**. }\end{array}$ & 1.00 & No & Outstanding \\
\hline $\begin{array}{l}\text { I believe that using multiple teaching techniques } \\
\text { improve the learning process**. }\end{array}$ & 1.00 & No & Outstanding \\
\hline
\end{tabular}




\begin{tabular}{|l|l|l|l|}
\hline $\begin{array}{l}\text { My colleagues strongly believe that multiple } \\
\text { teaching techniques should be used in all } \\
\text { courses**. }\end{array}$ & & No & Outstanding \\
\hline Reliability (Cronbach's alpha) & & & $\mathbf{0 . 6 4 6}$ \\
\hline
\end{tabular}

*Five-point scale: $1=$ strongly disagree to $5=$ strongly agree $* *$ Item was reverse coded.

\section{Analyses by job title and years of teaching experience}

A series of one-way ANOVAs were performed to determine if the job title of staff members affect their perceptions of the barriers to multiple teaching techniques. The results confirm that the job title of staff members do affect their perceptions towards only two barriers (Table 6). As the sample sizes of the independent variable (lecturers, associate professors and professors were not equal, post hoc tests (Hochberg's GT2) were employed to allow for pairwise comparisons between samples (De Vaus, 2002).

The results in Table 6 clearly show that there are significant differences among lecturers, associate professors and professors in terms of considering students and the classroom environment as barriers affecting the implementation of multiple teaching techniques. The post hoc tests showed that all the significant differences involved a pairing with professors. That is, staff members with the highest academic title significantly perceive students and the classroom environment as the only barriers affecting the implementation of multiple teaching techniques. Hence Hypothesis 1 is rejected because resources and lecturers' competence were not considered barriers affecting the use of multiple teaching techniques. This outcome supports previous arguments by Theall and Franklin (1991), suggesting that conquering obstacles to reach skillful, effective teaching strategies does support student learning goals and promotes knowledgeable creativity. The rejection of Hypothesis 1 may be because the targeted population was relatively small and the study was limited to one tourism and hotel faculty. If additional faculties and staff member were included in the study, the significance factor would have been improved.

Table 6. The impact of the job title on the perceptions towards each barrier

\begin{tabular}{|l|c|c|c|}
\hline \multicolumn{1}{|c|}{$\begin{array}{c}\text { Dependent } \\
\text { variables }\end{array}$} & Mean square & F & Significance \\
\hline Students barriers & \multicolumn{5}{l|}{} \\
\hline Between groups & 120.71 & 6.338 & $\mathbf{0 . 0 0 4} *$ \\
\hline Within groups & 18.961 & 9.136 & $\mathbf{0 . 0 0 1} *$ \\
\hline Classroom environment & & \\
\hline Between groups & 196.071 & 2.004 & 0.146 \\
\hline Within groups & 21.462 & & \\
\hline Resources availability & 7.071 & & 0.302 \\
\hline Between groups & 3.529 & 1.092 & \\
\hline Within groups & 6.286 & & \\
\hline Staff members competence & \\
\hline Between groups & 5.755 & & \\
\hline Within groups &
\end{tabular}

*Significant difference at $\mathrm{P} \leq 0.01$

Analyses by years of teaching experience revealed that there are significant differences regarding the perceptions of each barrier (Table 7). Hence, faculty members with more years of teaching experience perceive that students, the classroom environment, resources and lectures' competence impede the implementation of multiple teaching techniques. Therefore, hypothesis 2 is supported. This contradicts the results of Hutyra (2004). 
Table7. The impact of the years of teaching experience on the perceptions towards each barrier

\begin{tabular}{|l|c|c|c|}
\hline $\begin{array}{c}\text { Dependent } \\
\text { variables }\end{array}$ & Mean square & F & Significance \\
\hline Students barriers & 113.106 & 12.716 & $\mathbf{0 . 0 0 0}^{*}$ \\
\hline Between groups & 8.895 & & $\mathbf{0 . 0 0 0}^{*}$ \\
\hline Within groups & 230.274 & 102.344 & \\
\hline Classroom environment & & $\mathbf{0 . 0 0 0}^{*}$ \\
\hline Between groups & 2.250 & 68.933 & \\
\hline Within groups & \multicolumn{5}{|l|}{} \\
\hline Resources availability & 0.545 & 8.025 & $\mathbf{0 . 0 0 0}^{*}$ \\
\hline Between groups & 15.205 & & \\
\hline Within groups & 1.895 &
\end{tabular}

*Significant difference at $\mathrm{P} \leq 0.01$

\section{Conclusions and Recommendations for Further Research}

The use of multiple teaching techniques in the Egyptian faculties of tourism and hotel management can improve the quality of learning in these faculties. Applying these multiple teaching techniques requires overcoming all the perceived barriers. The present study revealed that the staff members' considered fourteen potential barriers out of twenty-three barriers to be outstanding and did not affect the implementation of multiple teaching techniques. However, the accessibility to up-to date classroom equipment is one of the most critical barriers affecting the use of multiple teaching techniques.

For a successful implementation of multiple teaching techniques in tourism and hospitality education, the following recommendations should be taken into consideration:

1. Overcoming perceived barriers to utilizing multiple teaching techniques must become the prime objective for any faculty of tourism and hotel management in Egypt to offer better learning opportunities to students. This can be done by expanding professional knowledge to lecturers and professors and enhancing teaching techniques.

2. Multiple teaching techniques awareness building should be encouraged among academic staff in the faculties of tourism and hotels. This can be attained through organizing a number of courses, workshops, focus groups, networks, seminars, etc. related to the professional development of university lecturers. Doing this will help disseminate knowledge of the utilization of multiple teaching techniques and remove any ambiguity or resistance that may arise in the future.

3. The faculties of tourism and hotel management in Egypt have no choice to regularly upgrade to modern technology. Inadequate resources for buying up-to-date teaching equipment can ruin any institution's image of being on the "cutting-edge" of modern technology. Any faculty with a poor financial plan for purchasing equipment and maintenance of modern technology risk the possibility of putting itself out of education business.

4. Faculties and institutions of tourism and hotels should organize tailored training programs based on a thorough assessment of their needs to enhance the skills and competencies of their academic staff.

\section{Limitations and Further Research}

The current investigation was limited to one Egyptian tourism and hotel faculty in one university. The generalization of the results to other faculties is, therefore, illogical. Thus, it is suggested to broaden the survey with other faculties and institutions in Egypt. Further research is also needed to investigate the barriers affecting the implementation of multiple teaching techniques in countries other than Egypt. Finally, it is also recommended to investigate if there are significant differences in the learning outcomes of students when multiple teaching techniques are employed. 


\section{References}

- Adams, B. (2010). The effects of experiential teaching method versus lecture based teaching method on student achievement. M.Sc. Dissertation. University of Georgia, USA.

- Afifi, H. (2011). E-learning as an alternative strategy for tourism higher education in Egypt. Quality Assurance in Education, 19 (4).

- American Society for Training and Development, (1989). How to design training rooms. (Darraugh, B., Ed.). Alexandria, VA: INFO-LINE Series

- Cakula, S. (2006). Information Technologies and E-Learning in the Studies of Tourism. ICTE in Regional Development: Annual Proceedings 2006. p13-18.

- Chang,Y. and Chang,W.(2012). Effects of E-learning on learning performance- A Case Study on students in tourism department in Taiwan, Pakistan Journal of Statistics, 28 (5), 633-644.

- Chopoorian, J., Karakaya, F. and Ainscough, T. L.(2001). The effects of class size and learning style on student performance in a multimedia-based marketing course. Journal of Marketing Education, 23(2), 84-90

- Chou, J. (2006). Welcoming the new e-era to discuss the e-learning of public servants. Forum on Training and Development, 71, 38-45.

- De Lorenzo, R. A. and Abbott, C. A. (2004). Effectiveness of an adult-learning, self-directed model compared with traditional lecture-based teaching methods in out of hospital training. Academic Emergency Medicine, 11 (1), ProQuest Central.

- De Rose, M., Marchiori, E., Kalbaska, N., Cantoni, L. (2014). Independent e-learning offers in Tourism and Hospitality: In search of a map and possible quality indicators. E-Learn Center Research Paper Series, 8, 45-55.

- De Vaus, D. (2002). Surveys in Social Research. London: Routledge.

- Elsayed, Y., Essawy, M., Helal, S., Gadelrab, R. (2011). Egyptian tourism higher education students' perceptions towards active and traditional learning. Egyptian Journal of Tourism Studies, 10 (1/2), 65-87.

- Eraqi, M., Abou-Alam, W., Belal, M., and Fahmi, T. (2011). Attitudes of undergraduate students toward e-learning in tourism: The case of Egypt. Journal of Teaching in Travel \& Tourism, 11, 325-348.

- Ghany.M and Latif. M. (2012). English language preparation of tourism and hospitality undergraduates in Egypt: Does it meet their future workplace requirements. Journal of Hospitality, Leisure, Sport and Tourism Education, 11, 93-100.

- Hamza,G. (2009).Mapping the doctoral theses awarded by the Egyptian Tourism colleges,1975-2008. Proceedings of the $2^{\text {nd }}$ WSEAS international conference on cultural heritage and tourism (pp. 91-100). Greece: Rodos.

- Hanson, S. and Moser, S. (2003). Reflections on a discipline-wide project: Developing active learning modules on the human dimensions of global change. Journal of Geography in Higher Education, 27(1), 17-38.

- Hourigan, S. (2011). Statistical Analysis in Social Sciences. New York: John Wiley \& Sons.

- Hundley, A. (2007). A comparative study of traditional lecture methods and interactive lecture methods in introductory geology courses for non-science majors at the college level. PhD Thesis: The Ohio State University, USA.

- Hutyra, J. (2004). Analysis of perceptual differences among department chairs, faculty and instructors toward the barrier to using multiple teaching strategies in two-year technical and community college electronic courses. PhD thesis: University of North Texas.

- Junco, R. and Mastrodicasa, J. (2007). Connecting to the next generation: What higher education professionals need to know about today's students. Washington, DC: NASPA

- Lin, B., and Hsieh, C. (2001). Web-based teaching and learner control: A research view. Computers and Education, 37, 377-386.

- Liburd, J., Hjalager, A., and Christensen, F. (2011). Valuing tourism education 2.0.Journal of Teaching in Travel and Tourism, 11(1), 107-130.

- Littlejohn, D. and Watson, S. (2004). Developing graduate managers for hospitality and tourism. International Journal of Contemporary Hospitality Management. Vol. 16, No.7.

- Malhotra, M., and Saunders, D. (2010). Education Research. London: Routledge.

- Minocha, S., and Thomas, P. (2007). Collaborative learning in a wiki environment: Experiences from a software engineering course. New Review of Hypermedia and Multimedia, 13(2), 187-209.

- (NAQAAE). National Authority for Quality Assurance and Accreditation in Education (2009). Academic standards of the Tourism and Hotels sector. Egypt: NAQAAE

- Prince, M. (2004). Does active learning work? A review of the research. Journal of Engineering Education, 93(3), 223231.

- Raybould, M. and Wilkins, H. (2005). Over qualified and under experienced: Turning graduates into hospitality managers. International Journal of Contemporary Hospitality Management, 17 (3). 
- Ruth, A., and Houghton, L. (2009). The wiki way of learning. Australasian Journal of Educational Technology, 25(2), 135-152. Retrieved from http://www.ascilite.org.au/ajet/ ajet25/ ruth.html. (Accessed: 15 December 2013).

- Scornavacca, E., and Marshall, S. (2007). Improving students' learning experience in the classroom through interactive SMS. Proceedings of the 40th Hawaii International Conference on System Sciences http://csd12.computer.org/comp/proceedings /hicss/2007/2755/00/27550005b. pdf (Accessed: 3 March 2013).

- Scott, N. (2007). An evaluation of the effects of using case method on student learning outcomes in a tourism strategic planning course. Journal of Teaching in Travel \& Tourism, 7(2), 21-34.

- Sigala, M. (2007). Integrating Web 2.0 in e-learning environments: A socio-technical approach. International Journal of Knowledge and Learning, 3(6), 628-648.

- Stahl, G. (2006). Group cognition: Computer support for building collaborative knowledge. Cambridge, MA: MIT Press.

- Theall, M., and Franklin, J. (1991). New Directions for Teaching and Learning: Effective Practices for Improving Teaching. San Francisco: Jossey-Bass Publishers.

- Trahan N. (2009). A Comparison of the Effectiveness of Two Alternative Instructional Strategies for Teaching Basic Construction Surveying Concepts. PhD Thesis: Louisana State University.

- Wolfe, K. (2006). Active learning. Journal of Teaching in Travel \& Tourism, 6(1), 77-82.

- Wyckoff, S. (2001). Changing the Culture of Undergraduate Science Teaching. Journal of College Science Teaching. 30 (5) . ProQuest Central.

- Zwyno, M. and Waalen, J.( 2001). Student outcomes and attitudes in technology-enabled and traditional education: A case study. Global Journal of Engineering Education, 5(1), 49-56.

\section{The questionnaire:}

\section{Part A: Your background information}

1. I am ...... ( Please choose the appropriate answer)
a- Lecturer
b- Associate professor
c- Professor

2. For how many years have you been lecturing in your faculty?

3. What is your department? (Please choose the appropriate answer)

a- Tourism studies b-Hotel management c-Guidance

4. Did you attend any staff development courses related to the use of multiple teaching techniques?

Yes No

Part B: Please rank the items below in terms of how strongly you feel each is a barrier to implement multiple teaching strategies. Choose only one response for each question.

SA = Strongly Agree, $A=$ Agree, $\mathrm{UN}=$ Undecided, $\mathrm{D}=$ Disagree, $\mathrm{SD}=$ Strongly Disagree

\begin{tabular}{|c|c|c|c|c|c|}
\hline 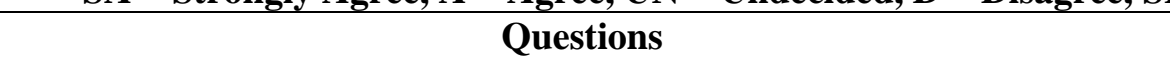 & SA & A & UN & D & SD \\
\hline $\begin{array}{l}\text { The large class size (number of students) is a barrier affecting the use of } \\
\text { multiple teaching techniques. }\end{array}$ & & & & & \\
\hline $\begin{array}{l}\text { Teaching to disabled students is a barrier affecting the use of multiple } \\
\text { teaching techniques. }\end{array}$ & & & & & \\
\hline $\begin{array}{l}\text { The age of my students is a barrier affecting my use of multiple teaching } \\
\text { techniques. }\end{array}$ & & & & & \\
\hline $\begin{array}{l}\text { Teaching courses with other staff members of my department is a barrier } \\
\text { affecting the use of multiple teaching techniques. }\end{array}$ & & & & & \\
\hline $\begin{array}{l}\text { Non-traditional students (e.g. open learning) are barriers affecting the use } \\
\text { of multiple teaching techniques. }\end{array}$ & & & & & \\
\hline $\begin{array}{l}\text { The lack of courses offered by my university in professional lecturer } \\
\text { development is a barrier affecting the use of multiple teaching techniques. }\end{array}$ & & & & & \\
\hline $\begin{array}{l}\text { The poor communication skills of my students are barriers affecting the } \\
\text { use of multiple teaching techniques. }\end{array}$ & & & & & \\
\hline
\end{tabular}




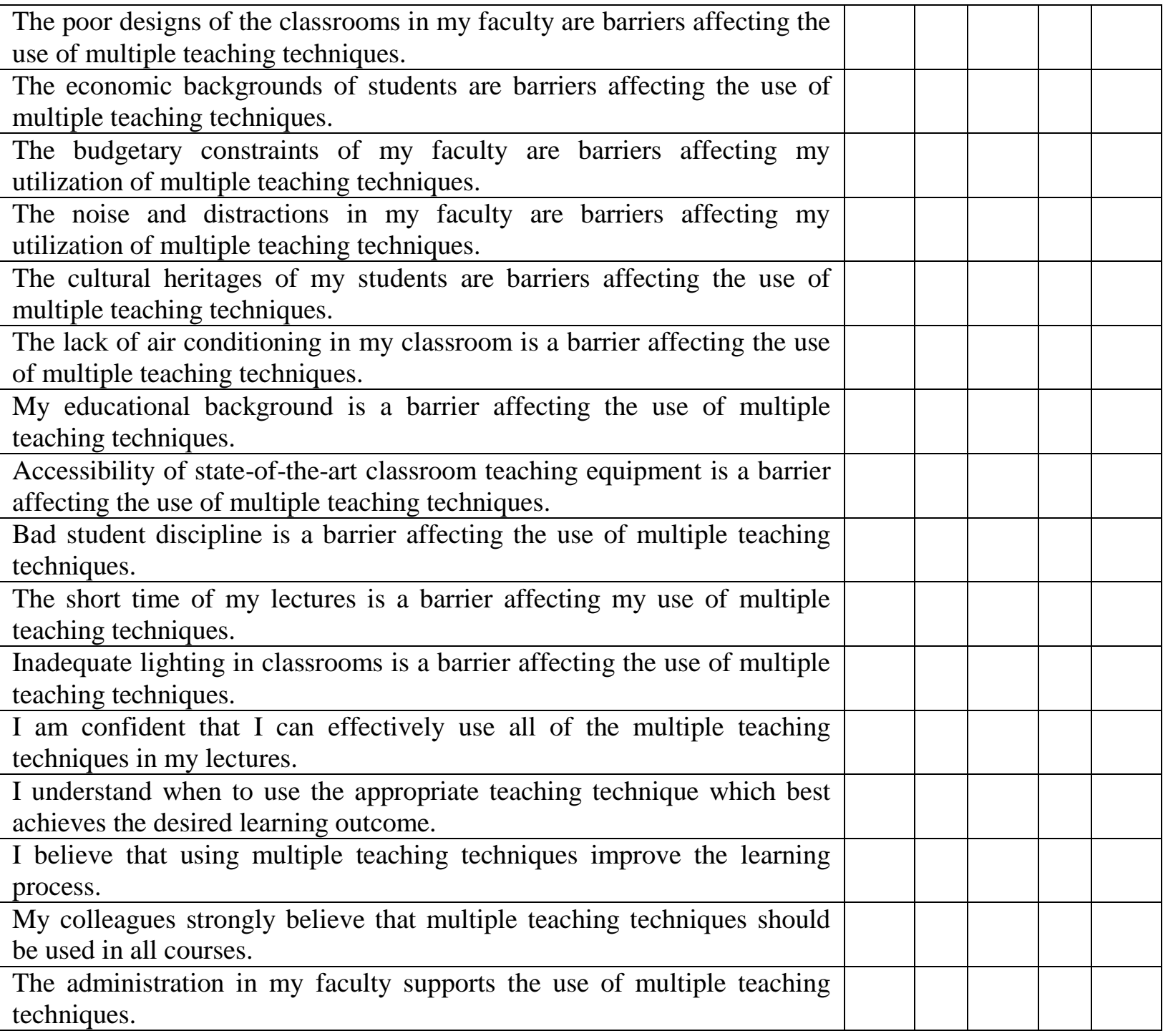

\section{معوقات تطبيق تقتيات التدريس المتعدده في مجال التعليم السياحي والفندقي العالي : دراسة حالة عن جامعة حلوان}

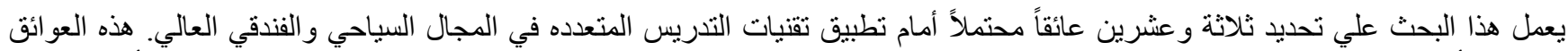

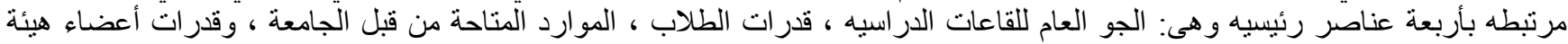

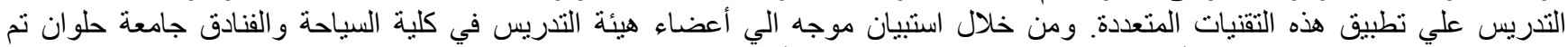

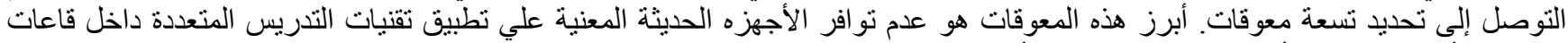

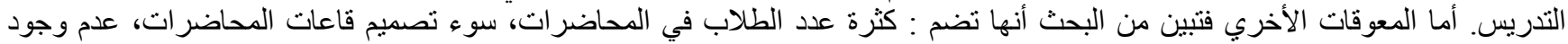

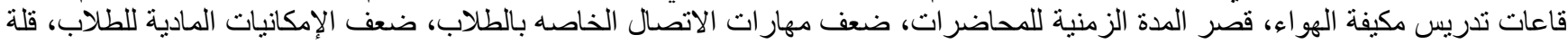

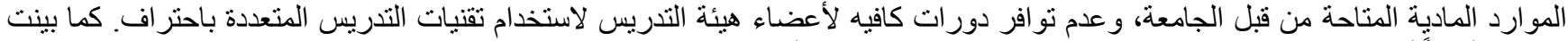

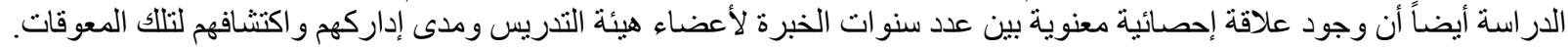

